\title{
Editorial Introduction Materializing Religion: Essays in Honor of David Chidester
}

\author{
Johan M. Strijdom \\ strijjm@unisa.ac.za
}

\section{Lee-Shae S. Scharnick-Udemans \\ lscharnickudemans@uwc.ac.za}

In his recent Religion: Material dynamics, David Chidester (2018) selected a number of key concepts that have preoccupied him during his forty years of studying religion. Having contributed to critiques of the concept of religion as a modern Western imperial and colonial invention, Chidester is intensely aware of the legacy of the term but has nevertheless employed it productively as an analytical term. If the academic study of religion, as heir of a Protestant bias, used to study beliefs, Chidester has been a pioneer in foregrounding material terms as a corrective in the study of religion, crediting Marx as crucial ancestor of this approach for his insight into the material basis of religion. The terms essayed in this book, considered under the title material dynamics, were selected by Chidester for the real, practical consequences they have had in the world, and were grouped under three sections: Categories, formations, and circulations.

Under categories, Chidester challenges us to reconsider a number of basic analytical categories in the academic study of religion: The prioritization of ideas over matter in imperial studies of religion; the Durkheimian opposition between sacred and profane in light of popular culture in which anything can be made sacred by intensive interpretation and ritualization; sacred time and space as historically contingent constructs that entail exclusions, hierarchies and contestations of ownership; and the crucial importance of the destabilizing 
concept of incongruity, which enables us to not only rethink myth and ritual, particularly in colonial conditions, but all categories in the study of religion.

Under formations, he insists that religion be studied in context, by embedding it within the cultural, economic, and political forces that have shaped religious formations and the academic study of religion: Capitalism as a material force has shaped religion, but also functions like a religion; imperialism, colonialism, and apartheid constituted material political and economic conditions that profoundly shaped and altered religious formations of the colonized and colonizers, but also contaminated the academic study of religion. If dominant religions and religious studies under these conditions have systematically dehumanized colonized people, the latter have simultaneously also been creative agents in their interactions with colonizers.

Circulations, properly theorized, he argues, focus our analytical attention on material changes, discontinuities and disruptions in space and time, as we track religious mobility, for example, in Zulu neoshamanism spreading globally through dreams and technology (as extensions of the conventional senses), and in sacred objects of economic exchange, such as 'fetishes' and cargo crossing oceans, or Tupperware and Coca-Cola being appropriated globally. Maintaining that the sense of touch is probably the most fundamental sense in our time, Chidester shows how it mediates religion materially by caressing and embracing on the one hand and striking on the other hand.

Reading through these chapters of the book, which were to a large extent previously published, but brought together in a particular way in Religion: Material dynamics, one is struck by numerous overlaps and intersections. The value of foregrounding a specific term, and giving it theoretical depth to analyze religious phenomena, has been proposed and experimented with by Chidester as a strategy to produce innovative or cuttingedge knowledge in the academic study of religion. Foregrounding one concept, though, has clearly not excluded the conscious exploration of its intersection with other concepts, as Chidester emphasizes in the Introduction ${ }^{1}$ to his

1 Chidester (2018:10) captures all of this particularly well in the following paragraph: 'The material dynamics of categories, formations, and circulations reveal different dimensions of Marx's rendering of the "spiritual intercourse" of human beings as an "efflux of their material condition". Categories reveal historical contingencies in thinking about religion; formations reveal forces at work in the 
selection of material keywords: It is in relating categories to formations, formations to circulations, circulations to categories, and in unexpected inversions of terms such as 'economy of religion' and 'religion of economy', that we might gain new perspectives in the study of religion and religions. Remarkable has been Chidester's keen eye for the intersection of disciplines, notably sociology and anthropology, to analyze religious cases exemplifying a key concept. At stake, as he always emphasizes, is an understanding of what it means to be a human being in a particular place and time, critically foregrounding the contested power relations that are created, maintained and challenged by religion as a human construct that works its real effects in the world.

When David Chidester moved from the United States to South Africa in the mid-1980s to take up a lectureship in comparative religious studies at the University of Cape Town, he soon realized that the violent context of apartheid demanded a reconsideration of his interest in the poetics of religion that he had valued so much during his studies and doctorate at the University of California, Santa Barbara, in the 1970s. From now on he would deliberately merge poetics and politics. He would retain his interest in the materiality of religion, but also increasingly informed by postcolonial critical theories, develop perspectives from a South African location within a global context.

Chidester has received several awards for his work. Analyzing systemic violence, he published Salvation and suicide: An interpretation of Jim Jones, the Peoples Temple, and Jonestown in 1988, and in 1991, Shots in the streets: Violence and religion in South Africa, which earned him an American Academy of Religion Award for Excellence in Religious Studies and a University of Cape Town Book Award respectively. Developing a critical analysis of the history of religious studies from a South African location, he published Savage systems: Colonialism and comparative religion in Southern Africa in 1996, and in 2014, Empire of religion: Imperialism and comparative religion for which he again received respectively an American Academy of Religion Award for Excellence in Religious Studies and a University of Cape

emergence of religious configurations; and circulations reveal the mobility of materiality pulsating through religion in motion. Each dimension provides openings for multidisciplinary engagements in the study of religion. They can also be related to each other in exploring the intersections of categories and formations, formations and circulations, and circulations and categories'. 
Town Book Award for its contribution to the decolonization of the academic study of religion. These awards are but a faint reflection of the contribution that David Chidester has made to the academic study of religion, as one can see from the extensive list of his publications that we have included at the end of this issue.

The essays in this volume are presented to honor David Chidester for the innovative, surprising, and substantial contributions that he has made to the field of religious studies within the South African context and internationally. Each of the authors engages with an issue that has been of major concern in David's work. As editors we have grouped these essays loosely under four sections.

In the first section, Decoloniality, Race, and Frontiers, Abdulkader Tayob argues that the Western study of religion can be decolonized by considering the use of the term 'religion' by modern Islamic intellectuals; Federico Settler examines contested relations between objects and black bodies within African religious contexts and indigenous knowledge systems; and Birgit Meyer proposes that Chidester's concept of the 'frontier zone' under colonial conditions may be productively employed to yield insights into contemporary European urban contexts of religious plurality as 'new postcolonial frontier zones'.

In the second section, Pop Culture, Fakes, and Plasticity, Kathryn Lofton engages with Chidester's work to explore the connection between the study of colonialism and pop culture; Paul Christopher Johnson argues with reference to Chidester's notion of 'authentic fakes' that the notions of 'fake' and 'authentic' are basic to the making of religion as well as the study of religion; and Asonzeh Ukah mobilizes the concept of 'plasticity' in Chidester to investigate the 'material dynamics' of a new religious movement in Uganda within changing political, economic, and cultural contexts.

In the third section, Senses and Media, Johan Strijdom compares and assesses Chidester's analysis of the 'senses' (understood as the conventional senses and their metaphorical uses, visions, and dreams, and new media as extensions of the senses) in European and indigenous African religions as well as the imperial study of religion, while Lee Scharnick-Udemans evokes Chidester's theory of 'wild religion' to elaborate an analysis of 'wild media' within the South African context, taking apartheid's banning of television as the devil and more recent responses of viewers to the television program, Lucifer, as case studies. 
In the fourth section, African Indigenous Religion, African Christianities, and the Future of Religion, Rosalind Hackett appreciates openings that Chidester's Wild religion (2012) creates for studying indigenous African religions in innovative ways. Sibusiso Masondo underlines the irony that while Christian missions were meant to be an instrument of European imperialism to civilize 'savage tribes', they created by means of their missionary schools African intellectuals, who would cultivate an ideology of African nationalism and unity in the interest of the liberation of the colonized. Jonathan Jansen shows how Christian beliefs of the mission-educated Oliver Tambo provided his deepest motivation to work, as prominent leader of the African National Congress, to bring about a just political system in South Africa. Martin Prozesky, drawing on Chidester's work, engages the divergent answers of two atheists to the question as to whether religion has a future, arguing that the divergence is due to their different views of what the term 'religion' refers to.

In the concluding appreciation, Ed Linenthal adds a personal note in which he celebrates a history of friendship, but also of professional collaboration. Linenthal echoes sentiments that can be observed throughout the contributions. The fondness with which many of the authors recall encounters with David - both personal and professional - hints at a legacy for which there is sadly no accolade in the academy. However, as can be discerned from this volume of essays, David's generosity, humor, and kindness, as friend, colleague, and mentor, are as appreciated and treasured as his intellectual contributions.

We thank the contributors for their articles, the peer-reviewers for their constructive comments, and our copy-editor, Willem Oliver, for his meticulous work. We also thank the executive committee of the Association for the Study of Religion in Southern Africa, of which David was the president for many years, for entrusting us to bring this Festschrift to fruition. The product, we think, is a gift worthy of honoring a great intellectual.

The list of publications at the end of this Festschrift gives an indication of the breadth and scope of Chidester's intellectual journey. We thank David for providing us with this list.

Finally, and most importantly, we wish David a productive retirement, which we hope will give him the opening to surprise us with even more innovative insights. 


\section{References}

Chidester, D. 1988. Salvation and suicide: An interpretation of Jim Jones, the Peoples Temple, and Jonestown. Bloomington: Indiana University Press.

Chidester, D. 1991. Shots in the streets: Violence and religion in South Africa. Boston: Beacon Press.

Chidester, D. 1996. Savage systems: Colonialism and comparative religion in Southern Africa. Charlottesville: University Press of Virginia.

Chidester, D. 2012. Wild religion: Tracking the sacred in South Africa. Berkeley: University of California Press.

Chidester, D. 2014. Empire of religion: Imperialism and comparative religion. Chicago: University of Chicago Press.

Chidester, D. 2018. Religion: Material dynamics. Berkeley: University of California Press.

Johan M. Strijdom Religious Studies University of South Africa strijjm@hotmail.com; strijjm@unisa.ac.za

Lee-Shae S. Scharnick-Udemans Desmond Tutu Centre for Religion and Social Justice University of the Western Cape lscharnickudemans@uwc.ac.za 